\title{
Quality of skins of commodity young stock of silver-black foxes grown in shads of different constructions
}

\author{
T. Shevchuk, \\ Candidate of Agricultural Sciences \\ Vinnytsia National Agrarian University
}

The purpose. To compare productivity of commodity young stock of silver-black foxes contained in standard 2-rows and redesigned from glasshouses 4-rows shads in different conditions of daylight illumination. Methods. Zootechnical, organoleptic, morphometric, physical methods of researches. Animals of control group were grown in standard 2-rows shads, of experimental - in 4-rows redesigned shad. Results. In standard 2-rows shads the maximum index of illuminance made nearby 1500 luxes, in 4-rows - less than 200 luxes. Flat-dry skins of commodity young stock of silverblack foxes grown in standard shads, were more longly, more widely - their square was more in comparison with skins of animals grown in 4-rows redesigned shad. However they were characterized by the worst colour, silveriness and had more imperfections of fur. Conclusions. Growing commodity young stock of silverblack foxes in standard 2-rows and redesigned 4-rows shads not only creates different conditions of daylight illumination, but also causes formation of fur products of different quality.

Key words: silver-black fox, growing, shads, daylight illumination, skin productivity, quality of fur.

Formulation of the problem. The cultivation of fur animals has a number of specific differences. In particular, foxes of cell proliferation are kept in open unburned premises or enclosures; Limited use of artificial lighting, mechanized distribution of feed and drinking, etc. [5, 14]. All this is dictated by the necessity to create conditions that are as close to natural as possible for industrial fur farming. After all, fur animals are still considered such that they have not completely lost their original instincts, therefore they often show hostility to man and fear $[2,4,11]$. Such behavior in response to the negligence of keeping animals can cause a decrease in productivity and, even, the death of animals.

An analysis of recent studies and publications has shown that foreign and domestic scientists and animal husbandry-practitioners constantly work to find optimum conditions for keeping animals $[3,4,10]$. The most important in zoo hygiene is the choice of type of premises, since today the economic circumstances encourage the domestic manufacturer to find ways to reduce the cost of construction [1, 7]. Therefore, often turning to the reconstruction of old buildings and the creation of atypical shields. In the literature, there are results of research on the productivity of mink and foxes grown in 4, 6-rowed shells, even with multi-tiered cages [6, 8, 13]. However, the effectiveness of using non-typical rooms, especially in the development of foxes, is practically not studied. Therefore, the purpose of our research was to compare the productivity of the stock market of young silver-black foxes, which were kept in typical 2-row and reconstructed from greenhouses in 4-row shelves.

Materials and methods of research. And the stage of the experiment was carried out on the marketable young of silvery-black foxes, which were held in 2 and 4 row cabinets, the illumination of which was different. The surveys were conducted from May to December 2012 according to the scheme presented in Table 1. 
Table 1. Scheme of Phase I research

\begin{tabular}{|l|l|l|l|}
\hline \multirow{2}{*}{ Groups } & $\begin{array}{l}\text { Number } \\
\text { animals }\end{array}$ & of & Peculiarities of conditions of detention for periods: \\
\cline { 3 - 5 } 1- Control & 120 & $\begin{array}{l}\text { Treparatory, 30 days } \\
\text { in 2-row passes }\end{array}$ & Basic, 200 days \\
\hline 2 - Experimental & 130 & $\begin{array}{l}\text { Transfer and placement } \\
\text { in 4-row passes }\end{array}$ & Hold in 2-row passes \\
\hline
\end{tabular}

Commodity young animals of 2 months of age were selected for live weight and formed two groups. The control was placed in two typical 2-row passes [6, 13], and experimental - in one 4-row. The latter is atypical, reconstructed from the greenhouse (Fig. 1).
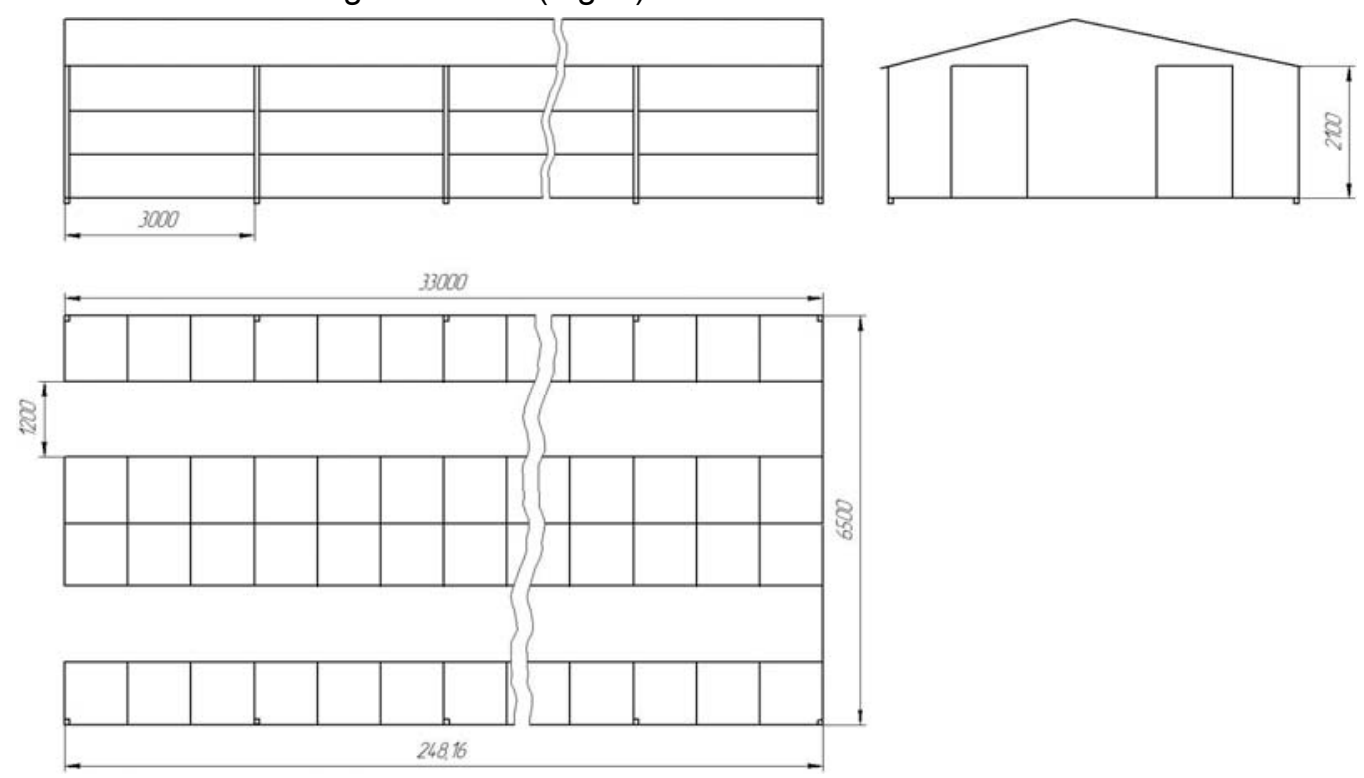

Fig. 1. Reconstructed 4-row shed for keeping foxes

$A$ - the view from the side, $b$ - the front view, in - the plan of the shade (1-mesh wings for commercial young foxes, 2 - passage between rows of cells)

The study of the level of natural light of the shields was carried out in accordance with the generally accepted rules [12] with the help of the lux-meter $U-117$, factory number 303 . The device was metrological verified as of 01.02.12, according to the schedule of the Vinnitsa branch of the RRT concern. The animals were kept and fed to the slaughter equally in accordance with the rules [15]. In NovemberDecember, they determined the maturity of fur and slaughtered. The skin was primed according to generally accepted rules [14]. Fresh-dry skin was evaluated according to GOST [16].

Research results. The study of the natural light of typical 2 and reconstructed 4-row shady showed that in the first maximum illumination index was about 1500 LK, and in the second - less than 200 Lk. Illumination maps are shown in Figures 2 and 3.

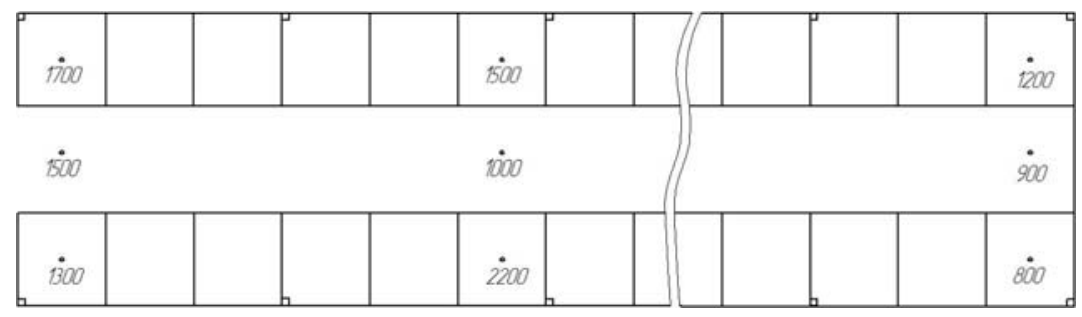

Fig. 2 The map of natural light of a 2-row shelf, $L k$ 


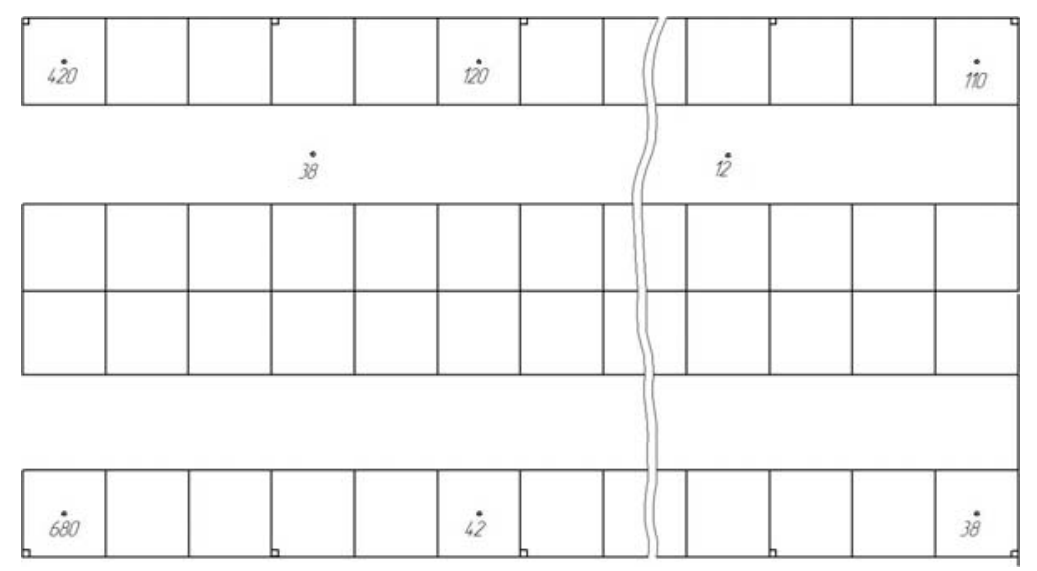

Fig. 3 The map of the natural light of a 4-row shelf, $L k$

The lack of natural light has negative effects on animal production and worsens working conditions. As in the passages of the 4-row shade at the level of cells and eyes of the farm worker at some points, the illumination does not exceed 12 - 42 LK (at rates not lower than $50-75 \mathrm{Lk}$ ), there is a need to develop ways to increase it at the expense of artificial.

Experimentally, it was found that the fresh-dry skin of commercial young silvery-black foxes that were kept in typical 2-row shells was $7.13 \%$ longer, $2.05 \%$ wider and had an area of $1.85 \mathrm{dm} 2$ in comparison with animals, Kept in a 4-row shade. At the same time, the difference was reliable (Table 2).

Table 2. Linear measurements and estimation of fresh-dry skin of commercial young fox grown in various shades

\begin{tabular}{|l|l|l|}
\hline \multirow{2}{*}{ Index } & Groups \\
\cline { 2 - 3 } & 1 - Control & 2 - Experimental \\
\hline Skin length, centimeters & $77,31 \pm 0,77$ & $71,80 \pm 0,59^{* * *}$ \\
\hline Width of the skin, centimeters & $13,23 \pm 0,03$ & $12,96 \pm 0,03^{* * *}$ \\
\hline Area of skin, square decimeters & 20,46 & 18,61 \\
\hline Skin evaluation,\% & $84,14 \pm 2,15$ & $71,19 \pm 1,87^{* * *}$ \\
\hline Price of skin realization, UAH & $708,50 \pm 18,95$ & $590,12 \pm 16,26^{* * *}$ \\
\hline
\end{tabular}

From the table data it is seen that the skin of the control animals was estimated at $12.95 \%$ higher and had a higher sales price of $118.38 \mathrm{UAH}$ than in the experimental group. This was due to the fact that the skin of slaughtered young, grown in a 2-row shell, had a larger size category, but was characterized by worse color, silver, and more flax defects (Table 3).

Table 3. Characteristics of qualitative indicators of fresh-dry skins of commodity youngsters of silvery-black foxes, grown in different shades, $\%$

\begin{tabular}{|l|l|l|}
\hline \multirow{2}{*}{ Index } & Groups \\
\cline { 2 - 3 } & 1 - Control & 2 - Experimental \\
\hline Dimensional category: & & 0 \\
\hline 0 & 0 & 0 \\
\hline 1 & 0 & 0,83 \\
\hline 2 & 5,08 & 9,09 \\
\hline 3 & 18,64 & 13,22 \\
\hline 4 & 24,58 & 52,89 \\
\hline 5 & 36,44 & 23,97 \\
\hline Color group: & 15,25 & 80,51 \\
\hline
\end{tabular}




\begin{tabular}{|l|l|l|}
\hline I & & \\
\hline II & 23,97 & 15,25 \\
\hline III & 7,44 & 4,24 \\
\hline A group of silver: & 81,36 \\
\hline III & 70,25 & 18,64 \\
\hline Group of bugs: & 29,75 & \\
I & & 80,17 \\
\hline 2 & 75,42 & 14,05 \\
\hline 3 & 14,41 & 4,96 \\
\hline 4 & 9,32 & 0,83 \\
\hline Grate: & 0,85 & \\
\hline II & & 85,95 \\
\hline II & 83,05 & 14,05 \\
\hline
\end{tabular}

The calculation of the economic efficiency of growing commercial young foxes of silvery-black fox in different cages showed that the production of fresh-dry in the 1 control group was more profitable than in the experiment at $137.52 \mathrm{UAH} / \mathrm{pc}$. Or $73.49 \%$ (Table 4).

Table 4. Economic appraisal of the efficiency of growing the commercial young of silvery-black fox in the shells of various designs

\begin{tabular}{|l|c|c|}
\hline \multirow{2}{*}{\multicolumn{1}{|c|}{ Index }} & \multicolumn{2}{c|}{ Groups } \\
\cline { 2 - 3 } & 1- Control & 2 - Experimental \\
\hline Number of animals in the group & 120 & 132 \\
\hline Conservation of livestock, \% & 98,3 & 91,6 \\
\hline The number of slaughtered youngsters & 118 & 121 \\
\hline Cost of 1 skin, UAH & 521,36 & 540,50 \\
\hline $\begin{array}{l}\text { The price of realization of 1 fresh-dry skin, } \\
\text { UAH }\end{array}$ & 708,50 & 590,12 \\
\hline Profit in the implementation of 1 skin, UAH & 187,14 & 49,62 \\
\hline
\end{tabular}

Consequently, keeping the stock of young silver-black fox in typical 2-row and reconstructed 4-row shelves not only creates different conditions for the microclimate, but also leads to the formation of products of different quality.

\section{Conclusions.}

1. 2-row and 4-row cables differ significantly in terms of natural light levels.

2. Animals grown in typical 2-row shells had larger linear dimensions of the skins obtained from them.

3. The foxes that were held in a reconstructed 4-row casing were characterized by a smaller size category of skin, however, a higher percentage of silver, skin and group color, as well as a smaller number of defects of groups 3 and 4 of defects.

\section{Bibliography}

1. Analysis, the problem is viable rozvytku zvirivnytstva v Ukrayini / [A. Poryts'ka, T. Shevchuk] // Stan a viable husbandry, pereerobky i vykorystannya produktsiyi tvarynnytstva y inshykh bioresursiv: materialy student · s'ko-uchnivs'koyi naukovoyi konferentsiyi. - For "yanets" - Podil's'kyy, 2013 - P. 35 - 37.

2. Afanasev V.A. Yzmenenye pushnyhh zverey pry razvedenyy v kletkakh / V.A. Afanas'ev - M., 1972. - P.33 - 37. 
3. Balakyrev N.A. Zverovodstvo v Hermanyy y Hollandyy / N.A. Balakyrev, E.H. Kvartnykova // Krolykovodstvo y zverovodstvo. -1998. - № 5. - S.23 - 24.

4. Balakyrev N.A. Modern problems of kletochnoho pushnoho zverovodstva Rossyy / N.A. Balakyrev // Aktual'nym problemam APK: materialy Mezhdunarodnoy nauchno-proyzv. Conf. - Kazan, 2003. - Ch.2. P. 288-293.

5. Bondarenko S.P. Soderzhanye lysyts / S.P. Bondarenko // Krolykovodstvo y zverovodstvo. - 2014 № 2 (12). - P. 54-59.

6. Budivli i sporudy dlya tvarynnytstva: DBN V.2.2-1-95. - Vydannya ofitsiyne. - K., Derzhkommistobuduvannya Ukrayiny, 1995. - Rezhym dostupu: http://profidom.com.ua/v-2/v-2-2/1482dbn-v-2-2-1-95-budivli-i -sporudi-dla-tvarinnictva.

7. Vakulenko I.S. Etapy rozvytku ta naukove zabezpechennya zvirivnytstva i krolivnytstva $v$ Ukrayiny I IS Vakulenko // Naukovo-tekhnichnyy byuleten '. - 2008. - Vyp. 97. - P. 8-12.

8. Vedeneev Yu.D. Chetysrekhryadnyy shed dlya norok / Yu.D.Vedeneev // Krolykovodstvo yzverovodstvo. - 1970. - № 6. - 35p.

9. Hyhyenycheskye trebovanyya $k$ mykroklymatu proyzvodstvennakh pomeshchenyy: SanPyN 2.2.4.548-96. - $\quad$ M., $1996 . \quad$ - $\quad$ Rezhym dostupu: http://www.medpravo.ru/PRICMZ/SanRules/1996/San2.2.4.548-96-3.htm.

10. Hladykov Yu.Y. Behlyy vz · hlyad na zverovodstvo v SShA / Yu.Y. Hladykov // Krolykovodstvo y zverovodstvo. - 2010. - № 4. - P.2-6.

11. Hubko O.T. Osnovy zoopsykholohiyi: navchal'nyy posibnyk / O.T.Hubko, S.I. Boltivets'. - K .: Svitohlyad, 2006 - 190 p.

12. Estestvennoe y yskusstvennoe osveshchenye: SNyP 23-05-95. - M., 1996. - Rezhym dostupu: www.vashdom.ru/snip/2305-95.

13. Zhyvotnovodcheskye, ptytsevodcheskye y zverovodcheskye zdanyya y pomeshchenyya: SNyP 2.10.03-84. - Vzamen SNyP II-99-77. - M., 1985. - Rezhym dostupu: http://www.vashdom.ru/snip/2100384.

14. Zverovodstvo: uchebnoe posobye dlya vuzov / [E.D. Yl'yna, A.D. Sobolev, T.M. Chekalova, N.N. Shumylyna]. - Spb .: Lan, 2004 - 304 p.

15. Perel'dyk N. Sh. Postanovka nauchno-khozyaystvennykh opytov po kormlenyyu pushnykh zverey / N.Sh. Perel'dyk, V.K. Yudyn // Metodycheskye ukazanyya. - M .: VASKHNYYL NYYPZK, 1973. - 19.

16. Shkurky lysytsy kletochnoho razvedenyya nevydalannye. Tekhnycheskye uslovyya: HOST 279088. - [Deystv. 01.10.1991]. - M .: Hos. Com After standard., 1988. - 15. - Vved. April 1, 1994.- 12 p. 